\title{
Considerações sobre as Teorias da Angústia em Freud ${ }^{1}$
}

Considerations about Freud's anguish theories

Maria Angélica Augusto de Mello Pisetta

Universidade Católica de Petrópolis

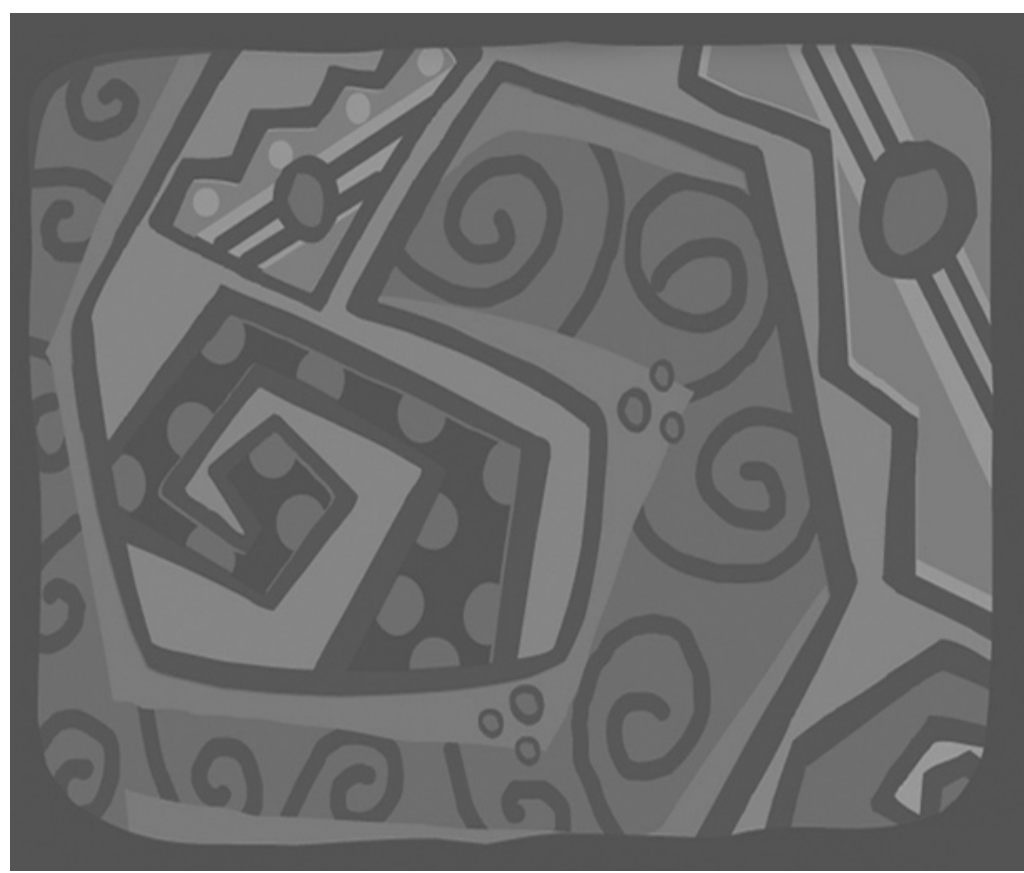


Resumo: Pretendemos discutir as duas principais formas de teorização do conceito de angústia desenvolvidas por Freud em suas relações com o conceito de recalque. Em um primeiro momento, situamos a angústia como afeto decorrente do recalcamento e, em virtude disso, sua condição de produto do mesmo. Nesta abordagem, ela não figura como algo originário, e ainda é passível de uma abordagem psicológica que a enderece a outro afeto. Em virtude da releitura de um caso de fobia e da noção de perigo, Freud retoma suas considerações e a situa como primordial e causadora do recalque e do próprio processo de constituição da subjetividade. Abordar a angústia na radicalidade do pensamento freudiano é algo necessário na consideração de seu manejo na clínica contemporânea. Para tanto, interpolamos alguns autores da psicanálise, incluindo o próprio Lacan, a fim de ampliar a discussão da função e do lugar da angústia na psicanálise.

Palavras-chave: Angústia. Recalque. Trauma. Psicanálise.

\begin{abstract}
Our purpose is to discuss the two main theoretical forms of the anguish concept in relationship with the repress concept developed by Freud. First we define anguish as an affection that sprang from repression and due to this, its condition as a product of the same repression. In our approach anguish doesn't appear as something original, so it is liable of a psychological approach that destines it to another affection. Due to a revaluation of a phobia case and of the danger notion, Freud reviews his considerations and defines anguish as primary, as the cause of repression and also of the exact process of the subjectivity constitution. The analysis of anguish in the radical aspect of the freudian concept is important considering the work in contemporary clinics. For this purpose we use some psychoanalytical authors, including Lacan, in order to enlarge the discussion of the anguish concept in psychoanalysis.
\end{abstract}

Keywords: Anguish. Repress. Trauma. Psychoanalysis.

\title{
Considerações sobre as teorias da angústia em Freud
}

\footnotetext{
1 Este artigo representa uma reformulação de um dos capítulos de minha dissertação de mestrado, intitulada "Da angústia o recalque numa passagem pela fobia" defendida em 01.10.1999, junto ao Programa de Pós-graduação em Psicologia do Instituto de Psicologia da UFRJ, sob orientação da prof. Dra. Vera Lúcia Lopes Besset.
}

Pretendemos considerar a teoria da angústia em Freud em dois momentos principais: em 1916-1917, teorizada como um afeto que incide posteriormente em relação ao recalque, como um produto deste último, e, num segundo momento, a partir de 1926, quando ela é considerada um afeto anterior e causador do recalque. Nesse segundo momento, portanto, ela é um indício de que o princípio regulador do aparelho psíquico, que quer a obtenção de prazer e a evitação de desprazer, falhou em sua ação. Ela é, pois, um anúncio da falência do princípio de prazer-desprazer, já que é percebida essencialmente como desprazerosa.
Entendemos que Freud se dedicava ao estudo do fenômeno da angústia sempre tentando articulá-la a um nível estrutural, como o faz na segunda tópica, buscando demarcar uma diferenciação da mesma em relação aos demais afetos. Vemos, por exemplo, em seu texto "Inibições, Sintomas e Ansiedade" (1926/1976, p. 189), que ele a considera como primazia devido ao caráter de "indefinição" e "falta de propriedade" que ela resguarda. Assim, há a consideração da angústia como única em seu caráter de paradoxo e resistência à síntese. Mas nós nos perguntamos, nesse primeiro momento: por que vê Freud a necessidade de postular 
Considerar a angústia sobretudo um afeto demonstra que não se pode considerá-la apenas algo provindo do recalque, portanto simbólica (nesse momento teórico, obviamente); mas algo que, acima de tudo, afeta. a angústia como algo que incide antes mesmo do recalque? Essa é a questão que movimenta nosso artigo e com a qual trabalharemos partindo essencialmente dos textos freudianos.

Até 1926, explicitamente, Freud definia angústia como um afeto que tomara essa tonalidade devido ao recalque. Por outro lado, destaca-se nitidamente seu caráter de "moeda corrente" como um afeto que serviria para tudo, pelo qual seria trocado qualquer afeto, desvinculado de sua idéia original após a separação efetivada pelo recalque (Freud, 1916-1917/1976). Assim, a angústia seria aqui uma amostra de que houve recalque, um anúncio e uma denúncia de que o eu negara acesso a alguma representação inconsciente. Dessa forma, ao mesmo tempo em que ela velava uma realidade, a da castração, ela a exibia. Havia ali ocorrido algo que não devia ocorrer novamente: a entrada de uma representação inconciliável, que denunciava a castração. A questão principal imiscuída aqui é a da origem do recalque, e, em conseqüência, da neurose. Assim, notamos um interesse essencial na "defesa" que, em "Inibições, Sintomas e Ansiedade", toma seu caráter de intervenção contra as moções pulsionais edípicas. Em 1916, Freud acentua que o problema da angústia "constitui um ponto no qual convergem os mais diversos e importantes problemas e um enigma cuja solução irá projetar intensa luz sobre toda nossa vida psíquica" (Freud, 19161917/1976, p. 458).

Freud coloca a angústia em posição privilegiada, enquanto constructo em sua teorização metapsicológica, e a sua definição é algo que será perseguido até o fim de seus estudos. Assim, ele vê a angústia como centro de suas investigações, derivando dela até mesmo o sintoma. Suas relações com o recalque já estão definitivamente demarcadas na primeira tópica e se aprofundam na segunda visão do aparelho psíquico.

Como bem ressalta Freud (1916-1917/1976), tematizar sobre a angústia implica a consideração permanente do fazer clínico. Lacan (1962-1963/2005, p. 13), nessa perspectiva, destaca que o analista é posto à prova na condução do tratamento, em relação à percepção do quanto de angústia pode seu paciente suportar, o que demarca um fenômeno e um conceito imprescindíveis para a psicanálise. Retomaremos Freud para indagar a pertinência e o alcance da função da angústia no processo analítico, pois, como bem acentua Harari (1997, p. 104): “Se bem que, enquanto analistas, sabemos que é decisivo saber dosar a angústia, não devemos deixar de ouvir o chamado desta, porquanto instala um toque de alerta - sinal - sobre a possibilidade de sufocação do desejo".

\section{A angústia enquanto afeto}

O afeto se caracteriza e é definido como algo que chega à consciência e provoca uma sensação. É, portanto, algo que se sente. Freud (1915b/1976) ressalta que, a rigor, não podemos falar em afetos inconscientes em virtude de sua essência perceptiva. Considerar a angústia sobretudo um afeto demonstra que não se pode considerá-la apenas algo provindo do recalque, portanto simbólica (nesse momento teórico, obviamente); mas algo que, acima de tudo, afeta. Essa contradição na definição (ser um afeto e, ao mesmo tempo, ser derivada do recalque) instrumentalizará a segunda teoria da angústia e a noção de sinal.

Freud (1926/1976) ressalta que ela, além do caráter claro de desprazer, é sempre acompanhada de sensações físicas - 
como distúrbios respiratórios e cardíacos, indicadores de seu caráter motor. Por este último, ganha importância a apreciação do caráter econômico na teorização da angústia, já que há uma intrínseca relação entre a descarga afetiva (que caracteriza a angústia) e a inervação motora. Dessa forma, ao nos referirmos à angústia, há sempre a consideração da quantidade de energia circulante no psiquismo. Contudo, se se trata do eu, notamos a implicação obrigatória da percepção desses atos motores para que a angústia possa se fazer notar na consciência. Assim, se analisarmos a fisiologia da angústia, encontraremos um aumento de excitação que encontra seu alívio em uma descarga motora. Em última instância, é na angústia que o ato encontra sua força energética (Freud, 1923/1976).

Freud indica ainda o ponto de vista histórico, que uniria, filogeneticamente, as sensações provenientes da angústia a tais inervações. O protótipo de situação onde isso ocorreria seria o trauma do nascimento, como veremos adiante. Os estados de angústia seriam, por esse prisma, uma reprodução de tal evento traumático.

Pelo processo de recalcamento, Freud pressupunha, na primeira tópica, que a pulsão se apresentaria em dois tipos de representação no psiquismo: idéia recalcada e afeto, que, entre seus destinos, poderia ser "trocado" por angústia. Como já enfatizamos, a angústia teria, assim, sobre os outros afetos, a condição de moeda universal, algo que lhe dava, desde o início, uma posição de privilégio; contudo, a ela não se relacionava uma certa logicidade em relação à representação associada, mas antes, um paradoxo, algo que não era condizente com a própria representação, ou seja, se ela pudesse "acompanhar" qualquer idéia separada de seu afeto primordial, ela guardaria com o recalcado uma proximidade lógica, o que nos remeteria a uma anterioridade em relação ao recalque. Assim, a angústia constitui um paradoxo, evidenciado na pressuposição de que é primordial aos demais afetos: "A ansiedade constitui moeda corrente universal pela qual é ou pode ser trocado qualquer impulso se o conteúdo ideativo vinculado a ele estiver sujeito à repressão" (Freud, 19161917/1976, p. 470).

Enquanto "moeda universal", é a angústia um afeto que fala tanto de "dentro" quanto de "fora" a partir do prisma do eu. "De dentro", ela acusa a castração, pelo processo de recalcamento, e, "de fora", relaciona-se aos objetos, nesse momento da teoria, e é trocada por raiva, temor ou qualquer outra tonalidade que melhor se associe a determinado objeto. Se "de dentro" ela nos fala da castração, é porque evidencia, já na primeira tópica, algo de inaceitável na consciência. Essa báscula entre o que é interno e o que é externo denota que a angústia demarca um limite, sendo ainda a própria expressão desse limite. Indicadora de uma divisão, ela pode ser considerada um "fenômeno de borda" (Harari, 1997, p. 43). Lacan abordará esse "interno-externo" sempre que se referir ao afeto, e, em especial, em O Seminário, Livro 10: a Angústia (1962-1963/2005), indicará uma não separação radical entre esses aparentes extremos na definição do objeto da angústia.

\section{Primeira teoria da angústia: a angústia é posterior ao recalque}

Desde os primeiros textos de Freud, a angústia aparece sempre vinculada ao recalque, quando é compreendida como emergência do recalcado. Sua incidência aqui manifesta 
"A base da própria repressão pode ser apenas uma sensação de desprazer, a incompatibilidade entre a idéia única que será reprimida e a massa dominante de idéias que constituem o ego. A idéia reprimida vinga-se, contudo, tornando-se patogênica"

(Freud, 1905/1976, p. 164). um processo anterior, bastante elaborado, alicerçado na sensação de desprazer. Freud postula a sensação de desprazer como base do recalque: "A base da própria repressão pode ser apenas uma sensação de desprazer, a incompatibilidade entre a idéia única que será reprimida e a massa dominante de idéias que constituem o ego. A idéia reprimida vinga-se, contudo, tornando-se patogênica" (Freud, 1905/1976, p. 164).

O desprazer relativo ao processo de recalcamento indica que o princípio do prazer está ligado ao controle de estímulos. O princípio do prazer é a modificação de uma realidade primária, uma inércia, que eqüivale para Freud ao prazer absoluto, ou seja, à ausência de estimulação. Ele é acionado para dar conta de uma quantidade de excitação não-ligada e constitui uma forma de modificação de uma realidade primária de excitações traumáticas e desamparo absoluto, como veremos melhor no tópico seguinte. Já o princípio de realidade é uma segunda fase para a continuidade de obtenção de prazer e, como seu predecessor, utiliza vários expedientes para alcançar sua meta. Em um primeiro momento, a angústia é vista como produto deste, como uma amostra de que ali houve uma luta incessante, concluída pelo recalque, para evitar a entrada de uma moção inaceitável que geraria mais desprazer do que a própria manifestação da angústia na consciência.

Tendo situado um pouco a relação do princípio do prazer com a angústia neste primeiro momento teórico, cabe-nos agora falar um pouco do recalque. De que recalque se trata na teorização da angústia? Podemos pensar em diferentes matizes da angústia, nos diversos tempos do recalcamento?

Como sabemos, Freud propõe uma divisão do recalque, o que nos faz pensar mesmo na sua observação da clínica, que incide todo o tempo na formulação teórica: uma primeira fase deste, ou recalque primitivo, uma segunda fase, ou recalque propriamente dito, e uma terceira fase, ou retorno do recalcado": "Uma primeira fase de repressão, (que) consiste em negar entrada no consciente ao representante psíquico (ideacional) do instinto. Com isso, estabelece-se uma fixação; a partir de então, o representante em questão continua inalterado, e o instinto permanece ligado a ele" (Freud, 1915b/1976, p. 171, grifos nossos).

Assim se estabelece a cadeia, com um ponto fixo inicial, chamado de fixação, que dará origem às substituições posteriores. Esse ponto fixo é uma quebra na continuidade existente no psiquismo. É como se houvesse energia livre, que agora se organiza através de um ponto de atração. Esse ponto de atraçãofixação não se desfaz pela significação, não toma outros sentidos, é antes a possibilidade de tal ocorrência; contudo, ele mesmo não retorna. Pensamos no recalque primário como a marca da divisão. Ele estabelece o limite em que há prazer para um determinado pólo de representações de atração libidinal, e concomitantemente, desprazer para outro. Assim, o recalque primário incide exatamente no cerne da divisão que inaugura um sujeito. É esse ponto de fixação que poderá fazer deslocar toda uma série de representações decorrentes. Nesse sentido, como nos lembra Lacan (1962-1963/2005, p.87), o recalcamento se apresenta como as "peneiras do reconhecimento". Vemos assim que haverá uma atração pela qual outros recalques se sucederão. Pensamos, com Cosentino (1993, p. 150), que o recalque originário não entra na cadeia associativa, mas é seu próprio suporte lógico.

O recalque propriamente dito, que incide como uma "pressão posterior"-Nachdrängen, 
Embora conciliador, pela busca do prazer perdido, o recalcamento é essencialmente separador em seu trabalho, e tem como efeito a falha. aparece como um deslocamento seqüencial desse ponto introdutório e fundador. Em assim sendo, o recalque de que temos notícia é o recalque propriamente dito, observado por Freud no fenômeno clínico da resistência. É pela resistência que podemos perceber o funcionamento das substituições dos representantes psíquicos da pulsão, que resguardam seu ponto de vinculação ao recalcamento. Então, podemos pensar nele também como uma tendência do aparelho psíquico de conseguir alguma satisfação, algum prazer, que em sua totalidade é vetado primordialmente. Embora conciliador, pela busca do prazer perdido, o recalcamento é essencialmente separador em seu trabalho, e tem como efeito a falha. Sempre falhará em sua busca, porque o que é recalcado continuará a exercer pressão pela satisfação.

A origem do recalque, como nos diz Freud, está na denegação da satisfação, na própria impossibilidade desta. A satisfação impossível figura como condição da subjetividade e balizadora do desejo. Freud nos diz que é aí que devemos buscar a essência do recalque: "Essa força falaz do instinto resulta de um desenvolvimento desinibido da fantasia e do represamento ocasionado pela satisfação frustrada. O fato de esse último resultado estar vinculado à repressão indica a direção em que a verdadeira importância da repressão deve ser procurada" (Freud, 1915b/1976, p. 172).

Nosso objetivo, ao tratar da primeira teoria da angústia, se restringiu especificamente a demonstrar que, para nós, Freud buscava um lugar para a angústia. Esse lugar, como entendemos, na primeira tópica, restringese à sua manifestação fenomenológica, já que ela se mostra, na clínica, posterior ao recalque, incidente no momento mesmo do recalque secundário. Freud a postula, assim, como um dos destinos do afeto, atravessado pelo recalque. Pensamos, contudo, que a angústia em seu caráter fenomenológico pode ser vista, na segunda tópica, com mais rigor, quando se the considera seu caráter lógico, como veremos a seguir.

\section{Segunda teoria da angústia: a angústia é anterior ao recalque}

Para acompanharmos a mudança paradigmática do conceito de angústia (como algo anterior ao recalque), destacaremos algumas considerações, a saber: a análise da fobia como o protótipo da neurose, o eu como a sede e o produtor da angústia (porque ela é eminentemente algo que se sente) e, finalmente, a concepção de um perigo real ou percebido como tal. Procuraremos articular essas considerações.

\section{A angústia como anterior ao recalque e à fobia}

As relações estruturais entre os conceitos de angústia e recalque em Freud obedecem a uma lógica que toma o estudo das defesas da fobia como primordial para sua remodelação. Retomando sua análise de Hans, Freud (1909/1976) vai ratificar suas conclusões acerca do perigo experimentado por Hans. Nesse sentido, ele destaca que a criança acredita que pode ser castrada pelo pai, e é aí que a angústia, como anterior, terá seu peso de empuxo ao recalque do desejo incestuoso pela mãe. Desse modo, torna-se necessária a consideração da angústia como anterior ao recalque. Como o perigo (a castração advinda do pai, aqui representado pelo cavalo) é repensado por Freud em termos de um perigo real, destaca-se que não há, ainda, recalcamento quando da incidência da angústia. Nesse sentido, o eu, 
não "preparado" para o perigo, se angustia, mobilizando a defesa do recalque.

A ansiedade pertencente às fobias a animais era um medo não transformado de castração. Era, portanto, um medo realístico, o medo de um perigo que era realmente iminente ou que era julgado real. Foi a ansiedade que produziu a repressão e não, como eu anteriormente acreditava, a repressão que produziu a ansiedade... É sempre a atitude de ansiedade do ego que é a coisa primária e que põe em movimento a repressão. (Freud, 1926/1976, p. 131, grifos nossos)

Embora considere que o perigo de que se trata, e a angústia que o anuncia, sejam realísticos, advindos "de fora", Freud não deixa de acentuar que a fobia é uma neurose, já que o objeto temido é constituído a partir da projeção. A fobia é tomada como modelo, protótipo da neurose, nesse sentido, à medida que o objeto (que produz medo e reação de fuga), como nos diz Freud, é um substituto do pai, também porque nestas, e sobretudo por isso, é mais claro o processo pelo qual a angústia é anterior ao recalque em função do perigo da castração ser percebido como real.

A defesa exercida pela fobia se mostra estável e eficiente, na medida em que não há o aparecimento da angústia. Esta se transforma em medo do objeto que, contudo, só aparece - o medo - na presença do objeto. Como nos diz Freud em "Inibições, Sintomas e Ansiedade", a própria formação dos sintomas está associada à evitação da angústia, e a formação do objeto temido obedece a essa evitação. Note-se aqui que a angústia é considerada tanto em termos originários (anterior à efetuação do recalque) quanto em termos de sinal, presente, ainda que indiretamente, na constituição da fobia. A partir da inscrição da angústia, e como ela é algo que se sente, o psiquismo promoverá meios de defesa, dentre os quais a fobia é modelar.

Notemos que a concepção de um real no perigo temido produz uma torção em torno da dinâmica da angústia. É uma pressuposição certamente controvertida e podemos pensar nisso como uma novidade na obra, mas, um pouco antes, em "Além do Princípio do Prazer", Freud já demonstrara que a pulsão é percebida como algo que incide de fora, um não-assimilável ao que se conhece do interno. Ele nos diz:

É certo que as excitações provenientes do interior serão, por sua intensidade e por outros caracteres qualitativos, mais adequadas ao modo de trabalho do sistema que os estímulos que afluem do mundo exterior... Com efeito, tender-se-á a tratá-las como se não atuassem de dentro, mas sim, de fora, a fim de poder aplicar-lhes o meio defensivo da proteção anti-estímulo. Essa é a origem da projeção, à qual está reservado um papel tão importante na causação dos processos patológicos. (Freud, 1920/1976, p. 45 , grifos nossos)

O que é "de fora" é algo de que se pode fugir, e, portanto, é passível de defesa. Em contrapartida, daquilo que é experimentado pelo eu como "de dentro" não se pode fugir. Em 1933, discutindo as funções do eu, Freud afirma que "o reprimido é terra estrangeira para o ego - território estrangeiro interno - assim como a realidade... é território estrangeiro externo" (Freud, 1923/1976, p. 75). A suposição de uma angústia realística, advinda do encontro com um perigo externo, como vemos, não convoca necessariamente a efetivação de um evento exterior aparentemente objetivo, mas a clivagem do eu, que toma como "de fora" o que lhe é mais íntimo. Nesse sentido, concordamos com Harari (1997, p. 55), que nos diz que “a angústia dá conta de que o sujeito não é 
A ansiedade é uma reação a uma situação de perigo. Ela é remediada pelo ego, que faz algo a fim de evitar essa situação ou para afastar-se dela... um unificado, irrompendo com sua certeza, com sua permanência". Pela manobra da projeção, isso se remodela, estabilizando o eu e promovendo o recalcamento onde antes só havia angústia. É essa a dinâmica na luta defensiva efetuada na fobia. O medo é tão só uma evitação da angústia, uma primeira apropriação significante e a forma neurótica mais próxima da angústia pura. Em assim sendo, não é mais a angústia um a posteriori. No percurso freudiano, ela é retomada e situada como original.

Notemos, então, que a angústia é associada definitivamente à castração, tomada no drama edípico como algo passível, inclusive, de reforço filogenético. A pulsão pode ser tomada como castração, pois sua inscrição se dá, imaginariamente, nesse momento, como a possibilidade de perda do que é mais caro no menino, o que o distingue da mulher, conforme o caso Hans. O perigo pulsional toma sua inscrição num objeto externo-interno (pai-cavalo), porque visto como castrador.

Como vimos, a conceituação de um internoexterno é o próprio cerne da discussão em torno da angústia e de seu objeto. Pela introdução da fobia como indicadora da borda que se produz em torno desse objeto, Freud nos aponta a necessidade de pensarmos na conceituação rigorosa desse objeto. Com a marcação em torno de uma angústia realística, ele parece salientar que a angústia não remete exclusivamente a um interno, já proporcionado por uma divisão que daria conta, em definitivo, da acomodação do sujeito na relação com o real. Harari (1997, p. 152), nesse sentido, afirma que: "a angústia suspende a vigência do mapeamento imaginário, que reconhece intuitivamente a diferença entre um de dentro e um de fora".

\section{A castração e a angústia: o perigo da castração}

Parece-nos aqui indispensável situar a importância do complexo de castração, incidente na fase fálica com a postulação da anterioridade da angústia em relação ao recalque. Do mesmo modo, destacaremos a re-significação possível, que se estabelece nesse momento, a todas as vivências de castração dos períodos antecedentes, que só a posteriori passam a ter significado. A situação de perigo atual - a da castração - é a possibilidade lógica da perda, como vemos nesta passagem:

\begin{abstract}
A ansiedade é uma reação a uma situação de perigo. Ela é remediada pelo ego, que faz algo a fim de evitar essa situação ou para afastar-se dela... Seria mais verdadeiro dizer que se criam sintomas a fim de evitar uma situação de perigo cuja presença foi assinalada pela geração de ansiedade. Nos casos que examinamos, o perigo em causa foi o de castração ou de algo remontável à castração. (Freud, 1976/1926, p. 152)
\end{abstract}

Esse trecho destaca que não é a angústia o que é evitado na formação dos sintomas, mas o perigo ao qual ela remete. Lacan (1962$1963 / 2005$, p. 31) salienta que as defesas não são construídas para barrar a angústia, mas sobretudo como resposta a algo a que ela remete, ao que ele nomeia, nesse seminário, de desejo do Outro e a conseqüente perda dos limites do sujeito. Entendemos que há aqui uma delimitação entre as duas abordagens, já que, em Freud, a presença da ameaça de castração pelo pai demarca uma ênfase no externo, enquanto, na abordagem lacaniana, a referência ao Outro da linguagem (Lacan) dá margem a uma não localização da ameaça de castração num outro qualquer, incluindo aí o pai castrador de que nos fala Freud. Para este último, a emergência da angústia decorre de uma relação desarticuladora que provenha da 
relação do sujeito com um outro localizado no pai castrador:

Declarei que as fobias têm a natureza de uma projeção devido ao fato de que substituem um perigo interno instintual por outro externo e perceptual. ... Essa minha afirmação não foi incorreta, mas não penetrou a superfície das coisas, pois uma exigência instintual não é, afinal de contas, perigosa em si; somente vem a ser assim, visto que acarreta um perigo externo real, o perigo de castração. Portanto, na fobia, no fundo, só se substituiu um perigo exterior por outro. (Freud, 1926/1976, p. 149 , grifos nossos)

O que remete à castração, na fobia, onde vemos o primado do falo, é a falta de equivalente ao sexo masculino. Em "Inibições, Sintomas e Ansiedade", aparece, com relação à fobia, essa surpreendente novidade, que revoluciona a teoria: a castração é percebida como externa e referente ao falo. Como substituto desse objeto, o objeto fóbico incide a partir da denegação da castração. Freud destaca a fobia como uma neurose "quase desenvolvimental", pois sua principal manobra é afastar o reconhecimento do pai simbólico e o do próprio sujeito: “...o afeto de ansiedade, que era a essência da fobia, proveio não do processo de repressão, não das catexias libidinais dos impulsos reprimidos, mas do próprio agente repressor" (Freud, 1926/1976, p. 131, grifos nossos).

Para entendermos então a castração, na sua vertente imaginária da angústia de castração do pênis e em sua vertente simbólica da falta no Outro, temos que cotejar a premissa infantil da universalidade do falo. A partir daí é que se pode, no Édipo, pensar em um reconhecimento da falta de pênis na mulher. O menino só pode reconhecer essa falta de pênis na mulher porque existe a premissa de que todos os seres têm o falo. Assim, porque todos têm - premissa fálica - alguns podem não tê-lo, posteriormente. É aí que o falo vai ser valorado como falo, a partir de uma falta. Entendemos, dessa forma, que a premissa é que introduz a dimensão simbólica da castração e a referência à falta simbólica.

A referência à falta em relação à angústia é, de longe, uma das mais utilizadas no campo psicanalítico. Quando Freud nos adverte que a criança recua, a partir da angústia, ao agente castrador, nos remete a uma fuga da castração e, em última instância, da falta. Podemos pensar, desse modo, que o neurótico recua diante da falta. É ratificando essa perspectiva que Lacan trabalhará a relação entre o desejo e a falta. Harari (1997, p. 104) discute a multipluralidade de usos que o termo falta convoca. Um primeiro sentido, freudiano por excelência, é o que demarca que a falta é percebida a partir do encontro com a castração. Recusar a castração, por sua vez, instauraria uma falta da falta. A castração aparece, nesse sentido, como algo a evitar, algo de que o sujeito se defende, a partir da angústia. Em contrapartida, adverte ainda o autor, a castração no ensino freudiano é normalizante e "será o complexo correspondente - e sua angústia concomitante - que permitirá 'superar' - dissolver - o Édipo" (Harari, 1997, p. 62). Em assim sendo, já podemos identificar em Freud um vetor de reconhecimento da função da castração junto à vinculação à cultura e conseqüente acesso ao desejo. A isso se acrescenta o fato clínico de que recusar a castração não implica, necessariamente, a emergência da angústia, especialmente nos casos clínicos da neurose, especificamente no caso Hans, já aludido por nós. Outro ponto importante a considerar é a íntima relação entre a castração (e a angústia suscitada por ela) e o falo, estabelecida a partir de 1923, no texto "A Organização Genital Infantil", a partir do que se considera 
ter como seu reverso o falo. A referência à falta se encontra no cerne da função do sinal de angústia emitido pelo eu. Mas como "funciona" o sinal e em que circunstâncias?

\section{O eu como produtor e sede real da angústia}

A questão fundamental na demarcação da operância do eu em relação à angústia é delimitar como se dá o processo do recalque sob a influência daquela. Freud diz que o eu percebe uma exigência pulsional que recriaria uma situação de perigo já experimentada; assim, o eu se prepara para evitá-la, retirar-lhe a força. Mas o eu não possui essa força, sendo fraco diante da insistência do isso. Freud ressalta que, nessa situação de enfrentamento, o eu se serve do que possui, recria em seus domínios uma pequena mostra do que seria a satisfação pulsional e assim permite a revivência da sensação desprazerosa. Dessa forma, o princípio do prazer é colocado em cena, efetuando o recalque da moção pulsional perigosa por intermédio do sinal do eu. É então em referência a um perigo superior que o eu produz o recalcamento, dirigindo-se a outra ordem que não a sua.

O ataque de angústia se desenvolve completamente, fazendo com que o eu se afaste do investimento censurável, e quanto mais angústia o eu enfrenta, mais ele se mobiliza para defender-se e vincular o recalcado. Essa tentativa angustiada do eu de se livrar da possibilidade do surgimento da moção inconciliável ocorre em função da operação da fantasia, que é o que lhe confere a tonalidade de perigo. Contudo, o processo descrito acima evidencia um recalque anterior, já que o sinal é originado com base numa divisão anterior.
Mas o que causaria o primeiro recalque, a partir do qual todos os outros se dariam? Como já vimos, Freud pressupõe que seria um trauma. O trauma é considerado externo, incidente a partir "de fora". Com a pressuposição de que o momento traumático seja então o fundamento do primeiro recalque a partir do qual a angústia aparece como sinal no eu, surge a questão da magnitude do trauma em relação ao aparecimento de sinais no eu. Assim, a incidência ou não de um momento traumático se deve à magnitude da energia em questão, assim como a paralisação do princípio do prazer e a conotação de perigo à experiência. Vemos em "Além do Princípio do Prazer": "Chamemos traumáticas as excitações exteriores que possuam força suficiente para perfurar a proteção antiestímulo" (Freud, 1920/1976, p. 45).

A angústia está antes do princípio do prazer, é mais primitiva e produzi-la se dá como proteção ao encontro com o traumático, o que pode ser percebido nos sonhos traumáticos e na repetição (Freud, 1919/1976). Dessa forma, nos diz Freud, na neurose traumática, os sonhos reproduzem uma situação de extremo sofrimento e repetição do trauma, não podendo, portanto, se referir ao princípio do prazer. Eles se refeririam antes a uma função anterior a este. Tal repetição poderia ser assim vista como uma tentativa de estabelecê-lo por meio do desenvolvimento da angústia, porque não houve possibilidade de sua atuação como sinal no momento da vivência traumática.

Indicam assim, via de regra, uma tentativa do estabelecimento do prazer, o que nos revela que ele - o princípio do prazer - não estaria aí estabelecido a priori. Pelo sonho traumático, Freud se deparou com um limite à sua concepção geral sobre os sonhos. É também a partir desse limite que Lacan 
(1964/1998) identifica um "inassimilável" do trauma. Do desprazer oriundo dos sonhos traumáticos, nada resta na vigília, ou seja, o sujeito não experimenta o horror do trauma, quando não está na emergência do sonho. Sendo assim, os sonhos traumáticos destacam algo bem distinto do princípio do prazer, pois não podemos identificar uma tentativa de domínio do desprazer que os acompanha. Lacan ressalta que se trata "do funcionamento mais primitivo - aquele em que se trata de obter a ligação de energia" (Lacan, 1964/1988, p. 52).

E já que a questão do trauma se resume à quantidade de excitação, por que não poderia esse momento traumático surgir em função de uma experiência traumática nova, sem referências a uma hipotética situação de perigo, e assim, sem possibilidade de um prévio sinal de angústia? A experiência clínica ampara essa "solução", e somente os recalques posteriores evidenciam o mecanismo pelo qual a angústia é despertada como sinal de um perigo ligado a uma situação prévia. Em se tratando de uma experiência traumática nova, haveria o surgimento da angústia automática. É por esse motivo que Freud considera que os momentos traumáticos sejam a fonte do estabelecimento dos recalques primitivos, no momento em que o eu não é capaz de lidar com as exigências muito intensas.

Não se pode mais afirmar, então, que seja a libido não-utilizada que causa a angústia, mas, em função dessa teoria do trauma, temos que admitir duas origens da angústia, uma conseqüente do momento traumático e outra como sinal que ameaça a repetição de um tal momento. Aqui transparece a necessidade lógica de a instância egóica ser considerada a produtora e a sede real da angústia.
Com a noção de conflito e divisão inaugurada pelo recalque, trata-se de levar a angústia em conta nas três instâncias - eu , supereu e isso. E é aqui que o sinal de angústia entra em consonância com a teoria. Para postulá-lo, é necessário que se tenha nova concepção da importância do eu nos processos psíquicos. Em 1926, Freud afirma que é o eu a sede real e o produtor de angústia. Ele se coloca da mesma forma diante de perigos externos ou internos. Nos externos, ele empreende tentativas de fuga, quer retirando o investimento do objeto perigoso, quer mobilizando movimentos musculares para afastar-se deste, ou seja, afastando-se da esfera de perigo. Ante o perigo pulsional, ele reage produzindo o sinal de angústia.

Lembremos que o eu, enquanto pólo de representações, é visto como um escravo de três senhores (o supereu, o mundo externo e o isso) em "O Ego e o Id." Com a nova teoria da angústia, essa posição é remodelada. $\mathrm{O}$ eu de agora é relativizado em sua fraqueza, justamente em virtude de sua ferramenta: o sinal de angústia. Contudo, Freud alerta para o fato de o novo eu não ser contraditório àquele escravo, conforme havia afirmado. Aqui ele apenas está considerando melhor o poder do eu em relação às outras instâncias.

A descrição de Freud do eu como a sede e o produtor da angústia é avaliada por ele como definitiva e em consonância com a exigência metapsicológica do que ocorre ao fenômeno da angústia observado na clínica. Apesar dessa afirmação, notamos uma incongruência nos limites do eu em relação às demais instâncias. Como centro e ordenador do psiquismo, liberando energias e "controlando" as moções pulsionais inconciliáveis, aparece um eu poderoso e capacitado; porém esse mesmo eu é indefeso diante de suas próprias produções. Com o recalque, ele retira de 
seus domínios uma parte importante de sua própria organização e empobrece toda a comunicação possível entre as demais instâncias. Dessa forma, o eu desse período toma toda sua força quando não está separado do isso, e só é fraco, "escravo", quando se coloca em oposição a este. Do mesmo modo, é estabelecida a relação eusupereu, quando só podemos distingui-los no momento do conflito.Toda a luta do eu para isolar moções inconciliáveis é, na realidade, uma tentativa de unir, de reconciliar, embora o recalque, e o conseqüente sintoma, tornem o eu cada vez mais empobrecido.

A concepção de que o eu é a sede da angústia, como dissemos, é definitiva na teoria freudiana, embora seja mais elaborada com a concepção de que a angústia do isso - ou angústia automática - é um fundo que pode fazer o eu produzir o sinal. Assim, Freud afirma que o recalque originário e os posteriores são motivados por uma angústia do isso. Haveria, a nosso ver, para Freud, uma re-apresentação constante, pelo sinal no eu, de uma falha já marcada no inconsciente (Pisetta, 2002). Em assim sendo, a angústiasinal revela algo que não está ali onde o sinal faz sua aparição.

Ressalta-se, com essa noção de uma angústia "inconsciente", ou de uma experiência que deixa esse traço, a situação de incompletude do aparelho psíquico, uma falta que o constitui falho, marca de sua dependência inicial diante do Outro: "Todo indivíduo tem, com toda probabilidade, um limite além do qual seu aparelho mental falha em sua função de dominar as quantidades de excitação que precisam ser eliminadas" (Freud, 1926/1976, p. 172).

Assim, não há como simbolizar tudo, indefinidamente. O que "escapa" a essa tentativa é representado pelo sinal de angústia no eu, e ainda assim a angústia vem como paradoxo, o de ser um afeto, e, por outro lado, uma expressão do inconsciente.

\section{A angústia e seu objeto}

É necessário sabermos que relação Freud postula entre a angústia e seu objeto causador. Com a suposição de que é o eu a sede e o produtor da angústia, a questão do objeto toma mais forma. Se é ele que produz angústia, embora seguindo um modelo já marcado no inconsciente, ele a produz diante de que objeto? Há uma anterioridade das marcas deixadas pela angústia em relação ao sinal no eu. Vemos, com isso, que o objeto da angústia é, de certa forma, tanto atual (percebido pelo eu em sua atualização) quanto antigo (que deixou marcas psíquicas de desestruturação do escudo protetor e promoveu a clivagem inaugural da subjetividade). Há aí um encontro tanto anterior quanto posterior.

Em contrapartida, toda a noção do objeto na teoria freudiana se alicerça nos efeitos simbolizantes do recalcamento, com a produção dos substitutos. Nesse sentido, se há um objeto para a angústia, ele não pode ser considerado a partir dos efeitos do recalque.

Como vimos, o objeto em Freud é entendido como decorrência do recalque, recalque esse que é, como entendemos, uma defesa contra o traumático que deixa as marcas da angústia como herança. Um objeto é composto, a partir do recalque, de uma nomeação, de uma apropriação pela linguagem. Tal conformação o torna passível de múltiplos sentidos, e cada sentido circunscreve um campo semântico possível.

Considerar o objeto algo posterior, algo possível apenas a partir do recalque com a instauração do psiquismo, encontra, a nosso 
ver, eco na pressuposição final do adendo ao principal texto de nosso trabalho: "Inibições, Sintomas e Ansiedade", em que Freud nos diz: "A angústia tem inegável relação com a expectativa: é angústia por algo. Tem uma qualidade de indefinição e falta de objeto" (Freud, 1926/1976, p. 189, grifos nossos).

A coerência com a premissa que ele estabelece neste texto, a saber, "a angústia é anterior ao recalque", o leva aqui, invariavelmente, a ter de considerar a ausência do objeto, como ele o entende, nessa relação inicial. Para nos repetirmos: Como pode haver objeto sem recalque? A indefinição de que nos fala, como característica inalienável da angústia, só pode ser por nós entendida como aquela que é forçosamente colocada de lado pelo recalque, para instauração da defesa (Cf. também Pisetta, 1996).

Interpolamos aqui a leitura lacaniana do objeto da angústia, a título de conclusão e questionamento. Para tanto, introduziremos brevemente o percurso de Lacan em torno da delimitação do objeto da angústia. No seminário sobre a relação de objeto (Lacan, $1956-1957 / 1995$, p. 252), Lacan concorda com Freud e descarta um objeto para a angústia, demarcando a necessidade lógica do recalque na conformação do objeto do desejo. Mas, mais tarde, em 1962-1963, em O Seminário, Livro 10: a Angústia, Lacan declara que o objeto da angústia não pode ser ligado às bases freudianas da delimitação do conceito de objeto, ou seja, a algo que provenha do recalque e da possibilidade de simbolização que este último confere.

Ele nos diz que o objeto da angústia nos remete a algo não objetivável, ao contrário, nos introduz na pura função da falta (Lacan, 1962-1963/2005, p. 99). Ser um objeto externo ao campo da objetividade não situa, por outro lado, o objeto da angústia como alheio em relação aos demais objetos do desejo. Pelo contrário, postulá-lo indica uma reordenação precisa ao campo geral dos objetos, já que ele se situa como a falta radical que, mantida, possibilita a circulação dos demais objetos.

Avaliar a angústia, dessa forma, exige considerações precisas em torno do conceito de objeto e uma reelaboração conceitual das possibilidades da existência de um objeto que não passem pelo recalcamento e pela simbolização que este último possibilita, esforço esse que nos acompanhará num momento posterior. 


\section{Maria Angélica Augusto de Mello Pisetta}

Doutora e Mestre em Psicologia pela Universidade Federal do Rio de Janeiro, professora e supervisora clínica da Universidade Católica de Petrópolis e da Especialização em psicanálise da criança da Santa Casa de Misericórdia - Hospital São Zacharias. Membro correspondente da Escola Brasileira de Psicanálise, seção Rio.

Endereço para correspondência:

Rua São Sebastião, n. 525, Bloco 9B, ap. 201

Bairro São Sebastião Cep: 25645-045, Petrópolis - RJ

E-mail: angelica.pisetta@ucp.br

Recebido 07/05/2007 Reformulado 20/03/2008 Aprovado 27/03/2008

Referências
Cosentino, J. C. (1993). Construcción de los conceptos freudianos. Buenos Aires: Manantial Estudios de Psicoanalisis.

Freud, S. (1976). Além do princípio de prazer. In S. Freud, Edição standard brasileira das obras psicológicas completas de Sigmund Freud (Vol. 18). Rio de Janeiro: Imago. (Trabalho original publicado em 1920)

Freud, S. (1976). Análise de uma fobia em um menino de cinco anos. In S. Freud, Edição standard brasileira das obras psicológicas completas de Sigmund Freud (Vol. 10). Rio de Janeiro: Imago. (Trabalho original publicado em 1909)

Freud, S. (1976). Conferências introdutórias sobre psicanálise. Conferência XXV. In S. Freud, Edição standard brasileira das obras psicológicas completas de Sigmund Freud (Vol. 16). Rio de Janeiro: Imago. (Trabalho original publicado em 1916/1917)

Freud, S. (1976). O ego e o id. In S. Freud, Edição standard brasileira das obras psicológicas completas de Sigmund Freud (Vol. 19). Rio de Janeiro: Imago. (Trabalho original publicado em 1923)

Freud, S. (1976). O estranho. In S. Freud, Edição standard brasileira das obras psicológicas completas de Sigmund Freud (Vol. 17). Rio de Janeiro: Imago. (Trabalho original publicado em 1919)

Freud, S. (1976). Inibições, sintomas e ansiedade. In S. Freud, Edição standard brasileira das obras psicológicas completas de Sigmund Freud (Vol. 20). Rio de Janeiro: Imago. (Trabalho original publicado em 1926)

Freud, S. (1976). A organização genital infantil: uma interpolação na teoria da sexualidade. In S. Freud, Edição standard brasileira das obras psicológicas completas de Sigmund Freud (Vol. 19). Rio de Janeiro: Imago. (Trabalho original publicado em 1923)
Freud, S. (1976). As pulsões e seus destinos. In S. Freud, Edição standard brasileira das obras psicológicas completas de Sigmund Freud (Vol. 14). Rio de Janeiro: Imago. (Trabalho original publicado em 1915a)

Freud, S. (1976). Repressão. In S. Freud, Edição standard brasileira das obras psicológicas completas de Sigmund Freud (Vol. 14). Rio de Janeiro: Imago. (Trabalho original publicado em 1915b)

Harari, R. (1997). O seminário - A angústia de Lacan: uma introdução. Porto Alegre: Artes e Ofícios.

Lacan, J. (1995). O seminário, livro 4: a relação de objeto. Rio de Janeiro: Jorge Zahar. (Trabalho original publicado em 1956/1957)

Lacan, J. (1988). O seminário, livro 11: os quatro conceitos fundamentais da psicanálise. Rio de Janeiro: Jorge Zahar. (Trabalho original publicado em 1964)

Lacan, J. (2005). O seminário, livro 10: a angústia. Rio de Janeiro: Jorge Zahar. (Trabalho original publicado em 1962/1963)

Pisetta, M. A. A. M. (1996). Da angústia ao recalque numa passagem pela fobia. Dissertação de Mestrado, Universidade Federal do Rio de Janeiro, Rio de Janeiro.

Pisetta, M. A. A. M. (2002). Fobia, angústia e castração. In V. Besset (Org.), Angústia (pp. 187-198). São Paulo: Escuta. 